\title{
Degree of Practice of Emotional and Spiritual Education by Faculty Members of Tafila Technical University and Its Role in Development of Self-Behavior from the Perspective of Students
}

\author{
Hani kraimeen ${ }^{1} \&$ Abd Al Raheem Al-Mhasnah ${ }^{1}$ \\ ${ }^{1}$ Department of Educational Psychology- Faculty of Educational Sciences, Tafila Technical University, Jordan \\ Correspondence: Abd Al Raheem Al-Mhasnah, Department of Educational Psychology- Faculty of Educational \\ Sciences, Tafila Technical University, Jordan
}

Received: August 9, 2017

Accepted: October 17, 2017

Online Published: October 24, 2017

doi:10.5430/ijhe.v6n5p181

URL: https://doi.org/10.5430/ijhe.v6n5p181

\begin{abstract}
This study aims to identify the practice of emotional and spiritual education by faculty members of Tafila Technical University and its relation in development of students' self-behavior, a notion that includes some aspects of self-emotions, behavior control, and emotional control and to guide a person towards achievement, excellence, in light of some variables like gender and specialization Al-Ahmad (2009). To achieve the goals of the study, a questionnaire was conducted to collect information to be distributed to a random sample consisting of 227 students (101 males and 126 females) in Tafila Technical University (TTU) in the academic year 2016/2017. The study concludes that the degree of practice of emotional and spiritual education and self-behavior by faculty members of TTU is average and that there is a correlation between spiritual and emotional values and self-behavior. According to these results, the study provides some recommendations including: to include contents of spiritual and emotional education in training programs for the faculty members of TTU, to develop teaching methods in universities in a manner that agrees with the moral curve that motivates students to develop self-discipline skills.
\end{abstract}

Keywords: Practice, Emotional and spiritual education, Faculty members

\section{Introduction}

Spiritual and emotional values constitute a key element in development of student's skills and regulation of their activities (Aspy, D.N \& Roebuck, F. N (1982). Educators have paid much attention to spiritual and emotional values. They further explained their significance in activating classroom learning, where they have adopted some values as basic rules to establish classroom environment and management and spread qualities of love, mercy, tolerance, just, honesty, forgiveness, good morals, purity, and self-discipline. The purpose for so doing was to establish value and moral balance and create an integrated system to combat forces of dark, violence, and extremism (Aspy, D.N \& Roebuck, F. N (1982). .

It should be pointed out that the spiritual and emotional values are strongly connected with Self-efficacy where they form self-discipline and agreement with daily life events, and reinforce self-discipline and reduce psychological pressures level (Thaher, 2004). Values of reflection, thinking, brotherhood, tolerance and modesty indicate to the integrity of the society. Further, similarity between students and teachers' values is a proof on success of the educational activity (Abdullah, 1999).

By definition, Spiritual and Emotional Values: mean to develop a person's emotions, feelings and attitudes and fulfill them so that their needs are met and their abilities and talents are developed. This leads to building a person's personality and effectively contributing to building the self-community. From the operational point of view, they mean degrees of students for their responses to the scale of degree of exercise of the spiritual and emotional values by the faculty members and its relation with behavior (Abd Al Rahman 1998) However, Self-behavior means to control behavior, exercise emotional adjustment and guide a person towards achievement to reach level of self-discipline that is based on the self-motivation to work, accomplishment and achievement of goals (Al-Ahmad, 2009).

Spiritual and emotional values contribute to developing self-awareness and acts which help to control emotions, exercise effective life, and manage acts and emotions in a flexible and effective manner (Hayari 2009). Also, they develop concept of the true management by which a person can achieve their goals, overcome obstacles and barriers 
and enter into a scientific and successful life (Ibid). Further, spiritual and emotional values motivate success and performance of jobs that require additional effort, guide and define behavior, reduce shame and difficulty of communication, and enable persons to identify their feelings and emotions and to deal with negative feelings like frustration (Ahmad, 2006).

Abu Amsheh (2013) further illustrated that the spiritual and emotional values are connected with the national education in order to fulfill the basic competencies of effective nationality to acquire and employ information, create new ideas, judge matters, make decisions based on accurate information, analyze and evaluate matters, create effective communication between various parties, and working in a teamwork to achieve the common goals and instill values of responsibility (Abu Amsheh, 2013). Adaptation of relationships among people and their emotions is an important quality a teacher should have, since the ground on which the educational processes is based requires establishment of positive and productive relationships with others. This cannot be achieved but fewer than two key dimensions, namely self-management and emotional sympathy with problems as well as providing realistic solutions (Sharef, 2017).

Al-Ahmad (2009) defines self-behavior means to identify a set of features including self-emotions, behavior control, emotional control and to guide a person towards achievement, excellence, not giving up to worry or defeated direction. Disciplined self-behavior means a positive ability to understand feelings and sympathy in the social context between students and friends, and between employers and employees; people are emotionally skillful where they read feelings and feel how to deal with them, and observe written and unwritten rules governing work at any institution (2009).

Further, behaviors contribute to the development of students' feelings and improve their adaptation of a person to himself and others, where he or she starts to realize their rights and obligations and undertake responsibility towards himself, his family and his entire nation. Thus, values reinforce powers and strengthen determination, resolution, optimistic feelings, and show wisdom as a result of interaction between the reason and moral controls, where wisdom lies in moderation in use of the reason. (Alwan, 2008).

\subsection{Significance of the Study}

This study is significant since it indicates to importance of the spiritual and emotional values in development of learners' self-discipline, promotion of commitment and discipline, engagement in hard work and achievement. It also highlights the relationship between the spiritual and emotional values and self-behavior. It further provides intellectual faith alternatives based on the principles of justice and moderation in facing results of obscurantist ideology that is based on extremism and violence. Eventually, it examines the new roles of a teacher in deepening problem-solving skills, self-understanding, persuasion and exercising the leading role of the classroom activities.

\subsection{Objectives of the Study}

The major objective for the current research is to identify the relationship between the spiritual \& emotional values and the self-behavior of students of TTU. Another objective is to identify to what extent teachers of TTU practice spiritual and emotional values and to identify the significant differences between arithmetic means of emotional and spiritual education in TTU's students attributed to variables of specialization and gender. In short, most students who study attend this university come from distant places and they live far away from their families, so they cook alone and eat alone. Sometimes, they stay away from their families more than two months. This study will be very important for Tafila technical students because, due to the geographic nature of the university, students will benefit from the results by starting to practice some of the strategies and techniques adopted in this study i.e., emotional and spiritual education.

It should be pointed out that Hayari (2009) conducted a study titled "Children's Emotional Education: Islamic vision". This study aims to explain how Islamic Education contributes to building the child's emotional aspect through mentioning the most important elements of the emotional education and the methods that lead to instilling them in a child. This study concludes that the Islamic Education curriculum is a comprehensive and balanced curriculum and that it goes beyond other curricula in paying attention to the child's emotional aspect.

Likewise, Ulwan (2008) tackled the idea of "Perceived Efficiency in Students of University of Baghdad". His study aims to identify perceived self-efficacy according to variables of the major and gender. The study sample consists of (275) students. The results showed that the study sample enjoys perceived self-efficacy and that there are statistically significant differences in perceived self-efficacy attributed to the variable of major in favor of the scientific specialization. 


\subsection{Limitations of the Study}

This study is generally limited to students of Tafila technical university students and university students who join universities in the south of Jordan. This is because these areas enjoy a very different atmosphere where people are very conservative. Also, the university is distant from urban places which makes most students feel alienated and homesick in all aspects of their lives, including food, living standards, and education.

\subsection{Problem of the Study}

Spiritual and emotional values constitute an integrated system in education that contributes to promoting students' self-discipline and deepening concept of self-control and accountability. This system also evaluates performance, helps to manage self effectively, and builds educated people characters on principles of commitment, attendance, achievement and excellence in work. Further, it contributes to combating phenomena of violence, bullying, and extremism, forming mind of educated people and guiding their interest, supporting cultural identity and coexistence, and providing learners with the ability to understand themselves and others and to amicably solve conflicts and disputes.

Julani (1997) and Abdullah (1999) show that student's performance in cases of emotional and spiritual education is improved due to acquiring a positive self-concept. Thus, the problem of the study can be defined in the following questions.

Questions of the study

This study will help respond to the following major questions:

1. To what extent do faculty members at TTU practice emotional and spiritual education?

2. To what extent do faculty members at TTU practice self-behavior?

3. Is there a statistically significant relationship between averages of emotional and spiritual education in TTU that can be attributed to variables of specialization and gender?

4. Are there statistically significant differences between averages of self-behavior in TTU attributed to variables of specialization and gender?

5. Is there a correlation between the practice of two degrees of emotional and spiritual values and degree of self-behavior point of view TTU's students?

\section{Literature Review}

Ali (2015) conducted a study titled "Development of Moral Values in Light of the Educational Thought of Imam bin Al-qayem". The study aims to identify the educational aspects that are aimed to improving the moral values in thought of Imam Bin Al-qayem. The study shows that there are intellectual and emotional aspects connected with the moral value according to Imam bin Al-qayem, where it defines a number of educational methods, including: to subjugate the teaching process to application of the scientific curve and connecting it with the educational activities and the moral and spiritual forces. Here, it is worth saying that Ali's study totally matches with the idea of the current study. i.e., there is an urgent need for emotional and spiritual education to help and support student in their academic excellence.

Drawing on the same theme and the significance of feelings (emotions) and education, Meng and Lowal, (2012) attempt to explore the relation between future feelings (worry, emotions, etc) and the personal expectation. Results showed that the case of worry for these students is low, and that there are no statistically significant differences in variable of gender and college between males and females, and that there are differences in variables of housing and academic achievement. The results also show that the self-organized students have high perception which drives them to success, and that the expected emotions affect self-esteem to strive for personal goals and self-organization.

Zubi's study (2006) addresses the school's desired role in the development of emotional and moral education, which helps in student's learning process and improvement of their characters, their ability to adapt to their environments, improvement of their experience and academic achievement, and organization of their learning process. Here is also a shared commonality with our study which denotes the positive feature of objectivity when applying spiritual and emotional education.

Like all the previous studies that highly focus on morality and education, Saqer (2005) investigated the level of moral and value growth and the perceived self-efficacy and their relationship among students at Yarmouk University. The study sample consisted of (654) undergraduate students. The results show that the large majority of the sampling units reach the second level of the moral growth and compliance with norms and laws, where there are individual 
statistically significant differences in level of moral growth and compliance with norms and laws, and there are individual statistically significant differences in level of moral growth attributed to variable or gender in favor of female students. Further, the study shows that the large majority of the sampling units reach the medium level of perceived self-efficacy attributed to the variable of gender in favor of meal students. The results show that there are no statistically significant differences in level of perceived self-efficacy attributed to the variable of specialization.

Supporting the same argument here, Graham (2003) developed a set of teaching strategies according to perception of emotional learning in terms of realistic, emotional, moral, social, spiritual and aesthetic dimensions. The study shows that emotional education is important to old people, where emotional education should involve cognitive contents, facts, concepts, instructions, terms and building of skills according to the emotional education, where this leads to promoting trends towards effective learning.

Similarly, Sheldon (1994) conducted a study that shows the importance of connecting curriculum with emotional education for its positive impact on the teaching-learning process, increased efficiency of teaching, cooperation between teachers and students, effective interaction in the classroom situations, positive participation in the learning process, contribution to development of community based school in which parents cooperate to solve its problems and participate in its plans and programs, as well as development of individual learning skills according to a comprehensive view of individualization of learning based on effort, speed, and capabilities. The best image is to form positive attitudes towards the effective learning based on problem and positive communication.

Hans et al. (1993) identify emotions and feelings that drive the future and role of an individual in the development of goals and concepts to improve performance and develop behavior. The study sample consisted of (472) students from University of Pennsylvania, University of Michigan, and University of Tilburg. The results showed that the worry of future emotions is low, and that the emotions driving future fall under two levels, namely expected emotions and anticipatory emotions which would positively affect a person to perform interesting and happy behaviors. Further, the study shows that achievement is realized through development of clear and measurable goals that drive a one to perform perfect jobs.

Like Hans et al (1993) and Sheldon (1994), Aspy and Eoebukc (1982) identified the role of emotional education in the educational process. The results of the study show that the emotional education is the true investment in the educational process not mere a surplus thing, since such education has economic significant impact on the educational institutions where it saves money and reduces the cost expended by schools, since it builds skills of integration with others and encourages students compliance with attendance and interaction, where students involve in learning effectively and learn about participation and cooperation to solve their problems.

Apparently, the previous literature has been helpful in building the theoretical framework of the study, formation and definition of the problem, determination of objectives of the study and the statistical method for analysis. It is also very beneficial in the discussion and definition of results, the determination of the objective of the study and the statistical method for analysis and discussion of results.

Having reviewed the Arabic and foreign literature, the present study attempts to identify effect of emotional education on elements of educational activity and its importance in development of the educational environment, saving time, effort and money, reducing maintenance burdens, as well as its positive impact on improvement of student's potential capacity, including emotional contents in the cognitive education goals that achieve affective design, teaching and implementation of the educational activities and school events.

Most studies are distinct as they address important topics. This study connects between the emotional and spiritual values and their impact on the self-behavior based on the self-discipline, and activating the student's self-review and control. It also asserts role of a faculty member in effectively including emotional and spiritual education while delivering the cognitive subjects so that it suits the students' needs and interests.

\section{Methodology and Procedure}

The Study Population and Sample:

The study population consists of all students of TTU (3699) for the academic year 2016/2017. A random sample consisting of (227) students (101 male students and 126 female students) was selected which represents $6 \%$ of the study population. Table (1) shows distribution of the sampling units according to variables of gender and specialization: It should be pointed out here that TTU offers only two types of awards: Science and Humanities. Also, it is worth mentioning that scientific majors are way higher than humanities due to the technical nature of the university. 
Table 1. The Sampling Units According To Variables of Gender and Specialization:

\begin{tabular}{l|lll}
\hline Total & Humanities & $\begin{array}{l}\text { Scientific } \\
\text { departments }\end{array}$ & $\begin{array}{l}\text { Specialization/ } \\
\text { gender }\end{array}$ \\
\hline 101 & 22 & 79 & Males \\
126 & 66 & 60 & Females \\
227 & 88 & 139 & Total \\
\hline
\end{tabular}

\subsection{The Study Tool: Data Collection Tools}

In order to achieve objectives of the study, the researcher prepared a questionnaire composed of two sections:

1. Degree of practice of emotional and spiritual education by faculty members of TTU; one domain,

2. Degree of practice of self-behavior by faculty members of TTU. For emotional and spiritual education, and (22) items for the degree of practice of the self-behavior by the TTU teachers. Accordingly, the total items of the questioner are (51), which is the final draft of the questionnaire.

Table 2. Domains of Practice of Emotional and Spiritual Education by Teachers of TTU in Development of Self-Behavior of TTU's Students.

\begin{tabular}{llll}
\hline Number of items & Numbers of questionnaire items & Domain & No \\
\hline 29 & $1-29$ & Spiritual and emotional Values & 1 \\
22 & $30-50$ & Self-behavior & 2 \\
51 & & &
\end{tabular}

\subsection{Validity of the Tool:}

To examine validity of the tool, we resorted to a conceptual construction method was used. The questionnaire, in its primary form, was presented during the past year of 2016/2017 to the subjects at Tafila Technical University. The questionnaire consists of (65) items, (36) items of which were intended for practice of emotional and spiritual education by faculty members at TTU from the student's perceptive, while (29) of which were intended for practice of self-behavior by faculty members of TTU from the student's perceptive.

The questionnaire was presented to a number of referees of the faculty members of Mutah University, University of Hussein bin Talal and TTU. The researchers requested the referees to provide their comments and opinions on validity of these items and their suitability to achieve objectives of the study, and how each item is suitable to the domain to which it belongs and to add any items they deem appropriate. After recovery of questionnaires from the specialized referees, appropriate additions, modifications and comments were added. After modification, the number of items became 29 items for practice of emotional and spiritual education by faculty members of TTU, and 22 items for practice of self-behavior by faculty members of TTU from the student's perceptive, where the final total items of the questionnaire became (51) which represent the final form of the questionnaire.

\subsection{Reliability of the Study Tool}

To examine reliability of the study tool, reliability coefficient was calculated using the internal consistency method according to Corbach Alpha for domains and the tool. The reliability coefficient for practice of emotional and spiritual values by faculty members of TTU was (0.96).

Table 3. Reliability coefficient using the internal consistency method according to Corbach Alpha for domains and the tool of the study

\begin{tabular}{lll}
\hline Internal consistency & Domain & No. \\
\hline 0.80 & Spiritual and emotional education & 1 \\
0.78 & Self-behavior & 2 \\
0.96 & Total & \\
\hline
\end{tabular}




\subsection{Variables of the Study:}

This study deals with the following variables:

\section{A. Independent variables:}

1. Gender variable: males and females,

2. Specialization variable: scientific departments and Humanities.

\section{b. Dependent variables:}

- practice of emotional and spiritual education by faculty members of TTU,

- Practice of self-behavior by faculty members of TTU from the student's perceptive.

\section{Results of the Study:}

Results of this study are presented below according to sequence of its questions:

\section{Results of Question 1:}

To what extent do teachers of TTU practice the emotional and spiritual education for the students' perspective?

Table 4. shows arithmetic means, standard deviations and rank of degree of spiritual and emotional values

\begin{tabular}{|c|c|c|c|c|c|c|c|c|}
\hline Degree & Rank & & $\begin{array}{l}\text { Standard } \\
\text { deviation }\end{array}$ & & $\begin{array}{l}\text { Arithmetic } \\
\text { mean }\end{array}$ & Item content & & $\begin{array}{l}\# \\
\text { item }\end{array}$ \\
\hline High & 1 & 3,60 & & 3,72 & & $\begin{array}{l}\text { He provides comprehensive } \\
\text { advice in scope of work }\end{array}$ & 9 & \\
\hline Medium & 2 & 1,20 & & 3,43 & & $\begin{array}{l}\text { A faculty member helps students } \\
\text { to improve communication skills }\end{array}$ & 1 & \\
\hline Medium & 3 & 1,24 & & 3,40 & & $\begin{array}{l}\text { He seeks to develop wisdom and } \\
\text { virtue to reach the true thought } \\
\text { that is based on values of right, } \\
\text { justice and moderation }\end{array}$ & 26 & \\
\hline Medium & 4 & 1,14 & & 3,34 & & $\begin{array}{l}\text { He addresses the positive motives } \\
\text { in students }\end{array}$ & 10 & \\
\hline Medium & 5 & 1,14 & & 3,27 & & $\begin{array}{l}\text { He has the ability of persuasion } \\
\text { and to positively affect student's } \\
\text { axioms }\end{array}$ & 23 & \\
\hline Medium & 6 & 1,20 & & 3,24 & & $\begin{array}{l}\text { He uses language of dialogue and } \\
\text { discussion to disapprove extreme } \\
\text { and destroying ideas }\end{array}$ & 24 & \\
\hline Medium & 7 & 1,20 & & 3,22 & & $\begin{array}{l}\text { He raises the morale of students } \\
\text { though advice and guidance }\end{array}$ & 12 & \\
\hline Medium & 8 & 1,20 & & 3.22 & & $\begin{array}{l}\text { He instill in students values of } \\
\text { forgiveness and tolerance }\end{array}$ & 8 & \\
\hline Medium & 9 & 1,30 & & 3,21 & & $\begin{array}{l}\text { He draws a bright image for the } \\
\text { future that is full of optimism and } \\
\text { positive energy }\end{array}$ & 19 & \\
\hline Medium & 10 & 1,20 & & 3,19 & & $\begin{array}{l}\text { He draws faith, social, moral, } \\
\text { emotional and intellectual image } \\
\text { through his meetings and lectures }\end{array}$ & 27 & \\
\hline Medium & 11 & 1,13 & & 3,17 & & $\begin{array}{l}\text { He incites students' emotions } \\
\text { towards learning }\end{array}$ & 2 & \\
\hline Medium & 12 & 1,20 & & 3,14 & & $\begin{array}{l}\text { His activities involve cooperation, } \\
\text { participation, problem solving } \\
\text { and self-understanding }\end{array}$ & 20 & \\
\hline
\end{tabular}




\begin{tabular}{|c|c|c|c|c|c|}
\hline Medium & 13 & 1,24 & 3,13 & $\begin{array}{l}\text { He seeks to protect students from } \\
\text { the dark thoughts }\end{array}$ & 16 \\
\hline Medium & 14 & 1,21 & 3,11 & $\begin{array}{l}\text { He analyzes negative and } \\
\text { criminal phenomena like } \\
\text { frustration, despair, and all types } \\
\text { of terrorism }\end{array}$ & 14 \\
\hline Medium & 15 & 1,32 & 3,11 & $\begin{array}{l}\text { He educates students about the } \\
\text { critical and creative thinking to } \\
\text { combat extremism and violence }\end{array}$ & 25 \\
\hline Medium & 16 & 1,30 & 3,11 & $\begin{array}{l}\text { He provides students with } \\
\text { positive energy that helps them to } \\
\text { be excellent }\end{array}$ & 5 \\
\hline Medium & 17 & 1,12 & 3,08 & $\begin{array}{l}\mathrm{He} \text { trains students to design } \\
\text { priorities for their emotional goals }\end{array}$ & 3 \\
\hline Medium & 18 & 1,24 & 3,08 & $\begin{array}{l}\text { He diversities his methods and } \\
\text { activities to build improved } \\
\text { intellectual system }\end{array}$ & 28 \\
\hline Medium & 19 & 1,20 & 3,07 & $\begin{array}{l}\text { He endeavors to build characters } \\
\text { of his students though shaping his } \\
\text { cognitive goals with moral, } \\
\text { spiritual and realistic dimensions }\end{array}$ & 17 \\
\hline Medium & 20 & 1,20 & 3,07 & $\begin{array}{l}\text { He elevates the students' feelings } \\
\text { and emotions to fulfill their needs }\end{array}$ & 18 \\
\hline Medium & 21 & 1,20 & 3,05 & $\begin{array}{l}\text { He can create a new knowledge } \\
\text { by deriving knowledge contents } \\
\text { contained in texts }\end{array}$ & 22 \\
\hline Medium & 22 & 1,20 & 3,03 & $\begin{array}{l}\text { He spreads happiness, optimism } \\
\text { and hope among students. }\end{array}$ & 7 \\
\hline Medium & 23 & 1,30 & 3,00 & $\begin{array}{l}\text { He provides intellectual } \\
\text { alternatives based on principles of } \\
\text { justice and moderation, }\end{array}$ & 15 \\
\hline Medium & 24 & 1,30 & 3,00 & $\begin{array}{l}\text { He effectively contributes to } \\
\text { building students' character and } \\
\text { their mental integrity }\end{array}$ & 29 \\
\hline Medium & 25 & 1,20 & 2,96 & $\begin{array}{l}\text { He trains students on awareness } \\
\text { of available alternatives }\end{array}$ & 4 \\
\hline Medium & 26 & 1,20 & 2,94 & $\begin{array}{l}\text { He psychologically supports } \\
\text { students and gets closer to them } \\
\text { spiritually }\end{array}$ & 11 \\
\hline Medium & 27 & 1,20 & 2,91 & $\begin{array}{l}\text { He provides deep and inclusive } \\
\text { conceptions about concepts of } \\
\text { extremism and fanaticism }\end{array}$ & 13 \\
\hline Medium & 28 & 1,30 & 2,84 & $\begin{array}{l}\text { He confesses his errors and does } \\
\text { not try to justify them }\end{array}$ & 21 \\
\hline Medium & 29 & 1,30 & 2,80 & $\begin{array}{l}\text { He attempts to reduce worry and } \\
\text { tension among students }\end{array}$ & 6 \\
\hline Medium & & 0,86 & 3,13 & Values in general & Total \\
\hline
\end{tabular}


Table (4) shows that arithmetic means range from 2.80 to 3.72, where item (9) "they provide comprehensive advice in scope of work" ranks first where the arithmetic mean is (3.72), standard deviation is (3.60) and the degree is high. While item (6) "they attempt to reduce worry and tension among students" ranks last, where the arithmetic mean is (2.80), standard deviation is (2.80) and the degree is medium. This may be attributed to the fact that the advice and instructions sometimes are not associated with the behavior, while reduction of the students' worry and tension requires training, exercise, inclusion of an emotional dimension in the knowledge and high ability of persuasion and influence. As to the total dimension, the arithmetic mean is (3.14) and the standard deviation is (0.86). This shows that the spiritual and emotional values system needs a cognitive dimension and an internal emotional dimension, training on commitment and behavior-discipline, and high abilities to persuade and influence others.

This study agrees with Saqer (2005) which shows that the majority of the study sample as medium, while disagrees with (Ulwan) which shows that the study sample has perceived self-efficacy, and with (Meng \& Lowa, 2002) which shows that the students with self-regulation have high perception. This could be attributed to the low academic level of students who are enrolled at these majors.

Table (5) below shows that arithmetic means range from 3.14 to 3.29, where item (32) " they He instill attitudes and values of respect for others in students " ranks first where the arithmetic mean is (3.29), standard deviation is (1.20) and the degree is medium. This may be attributed to the fact that the teacher-student relation needs the patter of relations based on respect and interaction with others. So, the teacher saves no effort to instill the concept and enhance language of dialogue and discussion. Item (47) "they effectively contribute to building students' character and mental integrity" ranks last with an arithmetic mean (3.00), a standard deviation (1.20) and low degree. This may require developing the teacher's knowledge on the psychological dimensions and how the psychologist understands the students. This dimension needs high degree of persuasion and influence of others, development of teaching methods, and inclusion of an emotional dimension in the knowledge. This result agrees with (Graham, 2003) which shows that the emotional education is important for young and adult people and that a cognitive dimension should be included in the emotional education, and with (Zubi, 2006) which shows the emotional and social education is very important.

As to the total level of this dimension, the arithmetic mean is (3.14) and the standard deviation is (0.93). This is due to the fact that the self-behavior needs spiritual values, high level of commitment, discipline, and emotional discipline and stimulating students to commitment.

Table (5) shows that there are no statistically significant differences between the spiritual and emotional values attributable to the variables of specialization and gender or their combination, where $\mathrm{F}$ value of the specialization variable is 0.002 , which is not statistically significant at the significance level $(0.05)$. F value for combination of specialization and gender is (0.112) which is not statistically significant at the significance level (0.05). This may be attributed to the fact that instilling the faith ethical philosophy and building of the emotional dimension and self-behavior are not affected by the specialization and gender, where all persons want to have values and combat phenomena of violence and extremism.

This study agrees with (Meng \& Lowa, 2002) which shows that there are not statistically significant differences in variable of gender in motivation and success domain, while disagrees with (Saqer) which shows individual statistically significant differences in ethical growth level attributable to the variable of gender in favor of females.

\section{Results of Question 2:}

To what extents do teachers of TTU practice self-behavior of student's point of view?

Table 5. Arithmetic Means, Standard Deviations, and Rank of Degree of Practice of Self-Behavior by Faculty Members of TTU

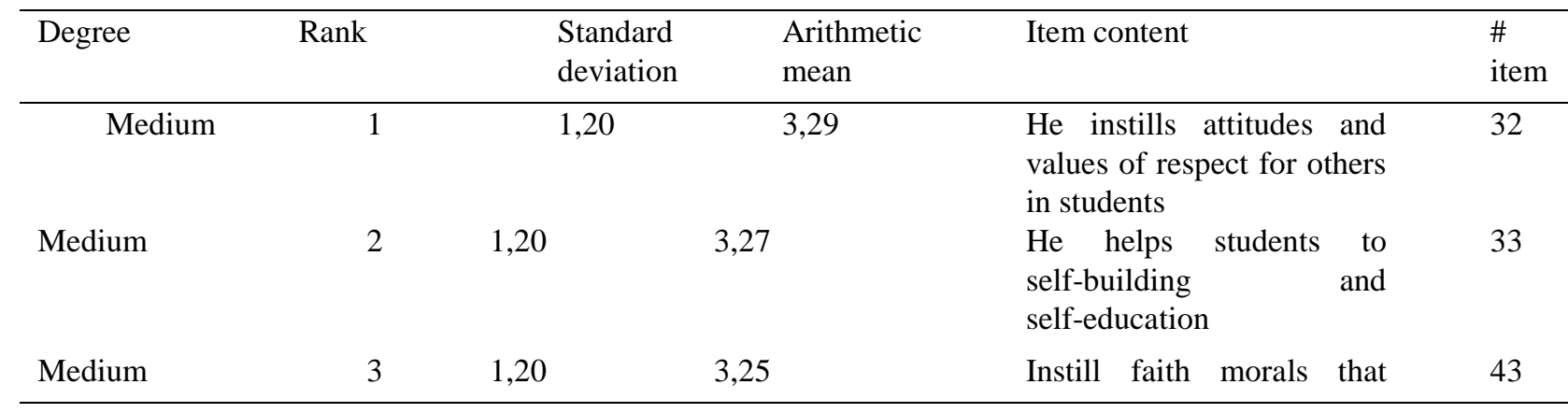




\begin{tabular}{|c|c|c|c|c|c|}
\hline & & & & $\begin{array}{l}\text { leads to self-discipline in } \\
\text { students }\end{array}$ & \\
\hline Medium & 4 & 1,30 & 3,20 & $\begin{array}{l}\text { He represents a good } \\
\text { example in his sayings and } \\
\text { deeds, }\end{array}$ & 40 \\
\hline Medium & 5 & 1,22 & 3,18 & $\begin{array}{l}\text { He helps students to build } \\
\text { positive identity towards } \\
\text { the self }\end{array}$ & 44 \\
\hline Medium & 6 & 1,30 & 3,18 & $\begin{array}{l}\text { He helps students to reform } \\
\text { and rationalize their } \\
\text { emotions }\end{array}$ & 34 \\
\hline Medium & 7 & 1,20 & 3,18 & $\begin{array}{l}\text { He helps students to have } \\
\text { and comply with spiritual } \\
\text { values like honesty and } \\
\text { faithfulness }\end{array}$ & 42 \\
\hline Medium & 8 & 1,17 & 3,17 & $\begin{array}{l}\text { He represents a good } \\
\text { example in his sayings and } \\
\text { deeds, }\end{array}$ & 45 \\
\hline Medium & 9 & 1,20 & 3,16 & $\begin{array}{l}\text { He builds the creative } \\
\text { thinking to fight forces of } \\
\text { extremism and violence }\end{array}$ & 31 \\
\hline Medium & 10 & 1,20 & 3,16 & $\begin{array}{l}\text { He helps students to } \\
\text { self-building } \\
\text { self-education }\end{array}$ & 46 \\
\hline Medium & 11 & 1,30 & 3,15 & $\begin{array}{l}\text { He trains students on } \\
\text { self-discipline skills that } \\
\text { activate students to } \\
\text { commitment and save time } \\
\text { and effort in learning } \\
\text { process }\end{array}$ & 49 \\
\hline Medium & 12 & 1,20 & 3,14 & $\begin{array}{l}\text { He deepens concept of self- } \\
\text { control and accountability }\end{array}$ & 35 \\
\hline Medium & 13 & 1,22 & 3,140 & $\begin{array}{l}\text { Instill in students skills to } \\
\text { reform and rationalize } \\
\text { emotions }\end{array}$ & 48 \\
\hline Medium & 14 & 1,31 & 3,14 & $\begin{array}{l}\text { He helps students in term } \\
\text { of psychological education }\end{array}$ & 30 \\
\hline Medium & 15 & 1,24 & 3,12 & $\begin{array}{l}\text { He instills in student the } \\
\text { faith moral that leads to } \\
\text { self-discipline }\end{array}$ & 38 \\
\hline Medium & 16 & 1,24 & 3,10 & $\begin{array}{l}\text { He helps students to have } \\
\text { and comply with spiritual } \\
\text { values like honesty and } \\
\text { faithfulness }\end{array}$ & 37 \\
\hline Medium & 17 & 1,22 & 3,09 & He helps students & 39 \\
\hline
\end{tabular}




\begin{tabular}{|c|c|c|c|c|c|}
\hline & & & & effectively manage self & \\
\hline Medium & 18 & 1,23 & 3,06 & $\begin{array}{l}\text { He effectively contributes } \\
\text { to building students' } \\
\text { character and mental } \\
\text { integrity }\end{array}$ & 41 \\
\hline Medium & 19 & 1,20 & 3,06 & $\begin{array}{l}\text { He helps students to } \\
\text { employee and control } \\
\text { psychological emotions to } \\
\text { be harmony with spiritual } \\
\text { values }\end{array}$ & 36 \\
\hline Medium & 20 & 1,22 & 3,02 & $\begin{array}{l}\text { He can manage attention of } \\
\text { students to fight violence } \\
\text { and extremism }\end{array}$ & 50 \\
\hline Medium & 21 & 1,30 & 3,01 & $\begin{array}{l}\text { He focuses on the applied } \\
\text { and practical aspect to } \\
\text { build world of conscience }\end{array}$ & 51 \\
\hline Medium & 22 & 1,20 & 3,00 & $\begin{array}{l}\text { He effectively contributes } \\
\text { to building students' } \\
\text { character and mental } \\
\text { integrity }\end{array}$ & 47 \\
\hline Medium & & ,93 & 3,14 & Total & \\
\hline
\end{tabular}

Table (5) shows that arithmetic means range from 3.14 to 3.29, where item (32) " they He instill attitudes and values of respect for others in students " ranks first where the arithmetic mean is (3.29), standard deviation is (1.20) and the degree is medium. This may be attributed to the fact that the teacher-student relation needs the patter of relations based on respect and interaction with others. So, the teacher saves no effort to instill the concept and enhance language of dialogue and discussion. Item (47) "they effectively contribute to building students' character and mental integrity" ranks last with an arithmetic mean (3.00), a standard deviation (1.20) and low degree. This may require developing the teacher's knowledge on the psychological dimensions and how the psychologist understands the students. This dimension needs high degree of persuasion and influence of others, development of teaching methods, and inclusion of an emotional dimension in the knowledge. This result agrees with (Graham, 2003) which shows that the emotional education is important for young and adult people and that a cognitive dimension should be included in the emotional education, and with (Zubi, 2006) which shows the emotional and social education is very important.

As to the total level of this dimension, the arithmetic mean is (3.14) and the standard deviation is (0.93). This is due to the fact that the self-behavior needs spiritual values, high level of commitment, discipline, and emotional discipline and stimulating students to commitment.

\section{Results of Question 3:}

Is there a statistically significant relationship between averages of self-behavior in TTU attributed to variables of specialization and gender?

To answer this question, arithmetic means and standard deviations for gender and specialization were calculated as shown in table (6) below:

Table 6. arithmetic means and standard deviations of TTU teachers' level of spiritual and emotional values according to gender and specialization variables:

\begin{tabular}{lllll}
\hline Humanities & & Scientific & Gender \\
\hline Deviation & Mean & Deviation & Mean & \\
0,89 & 3,07 & 0,78 & 3,12 & Males \\
, 93 & 3,18 & 0,91 & 3,14 & Females
\end{tabular}

Table (6) shows that the arithmetic means range from 3.07 to 3.18), and the highest arithmetic mean is (3.18) with a standard deviation of (0.93), while the lowest arithmetic mean is (3.07) with a standard deviation of $(0.89)$ as to the humanities. In order to identify significance of these arithmetic means, Two Way Anova was used, and the following 
table shows the results:

Table (6) also shows that there are no statistically significant differences between the spiritual and emotional values attributable to the variables of specialization and gender or their combination, where $\mathrm{F}$ value of the specialization variable is 0.002 , which is not statistically significant at the significance level $(0.05)$. F value for combination of specialization and gender is $(0.112)$ which is not statistically significant at the significance level (0.05). This may be attributed to the fact that instilling the faith ethical philosophy and building of the emotional dimension and self-behavior are not affected by the specialization and gender, where all persons want to have values and combat phenomena of violence and extremism.

This study agrees with Meng \& Lowa (2002) which shows that there are not statistically significant differences in variable of gender in motivation and success domain, while disagrees with Saqer which shows individual statistically significant differences in ethical growth level attributable to the variable of gender in favor of females.

\section{Results of question 4:}

Results of Question 4

"Are there statistically significant differences in degree of practice self-behavior by faculty members of TTU attributable to variables of specialization and gender? To answer this question, arithmetic means and standard deviations of the gender and specialization were calculated.

Table (7) shows that the arithmetic means range from 2.97 to 3.22, and that the higher arithmetic mean is (3.22) with a standard deviation of $(0.88)$ for females, while the lowest arithmetic mean is (2.97) with a standard deviation of (0.86) for males in humanities.

Table (7) also shows that there are no statistically significant differences in degree of practice of self-behavior by teachers of TTU attributed to variables of specialization and gender and combination of both, where F value of specialization is 0,311 , which is not statistically significant at significance level $(0,05)$. F value for gender is 1,54 , which is not statistically significant at significance level $(0,05)$. F value for combination of specialization and gender is 0,106 , which is not statistically significant at significance level $(0,05)$. This may be attributed to the fact that the self-behavior and self-discipline is an inevitable result of practice of spiritual and emotional values. Thus, students can be assisted in self-building, emotion modification, and commitment and attendance activation.

\section{Results of Question 5:}

Is there a statistically significant relationship between degree of practice of the emotional and spiritual values and the degree of practice of self-behavior?

Pearson correlation coefficient was used between the spiritual and emotional values and the self-behavior, where correlation coefficient is (0.805), which is statistically significant at the significance level (0.0). This may be attributed to the impact of the faith values that are based on the principles of justice, moderation, equality, wisdom, virtue and right on creating an environment that helps practice self-discipline and self-management, and develop skills of commitment, attendance, and building or self and personal identity.

This study agrees with (Graham, 2003), which shows the need to include cognitive concepts in the emotional education like facts, concepts, terms, skill building based on emotional education, and promotion of trends towards learning process in effective manner.

\section{Recommendations of the Study:}

1. Contents of spiritual and emotional educational should be included in training programs for faculty members of universities. Examples are numerous like when you provide students with different social means of contacting their families and hold some monthly meetings with their families.

2. The instruction of Values that contribute to development of student's emotions in order to develop their self-behavior should be included in courses and activities provided to students. Examples here could be to let these students mingle with the local community; know their habits and social behaviors.

3. Teaching methods in universities should be developed in a manner that agrees with the value and moral curve that supports student's self-discipline skills and activates them to work, achievement, respect for others and combating contemporary challenges like violence, determinism and dark thought. 


\section{References}

Abdallah, Abd Al Raheem. (1999). Emotional Results Of Academic Achievement, Journal Of Education, No.(129) Year (28), General Secretariat Of The Qatar National Committee For Education And Culture, Qatar, Doha, (138-140).

Abd Al Wahab, Sameer. (2006). Emotional Education Of The Child: Questions And Premises, Paper Presented At The Annual Conference Of The College Of Kindergarten, Cairo University " Emotional Education For The Child 4/9/2006, 41-51.

Abd Al Rahman, Saed. (1998). Psychometric Measurement. Al Falah Library, Kuwait.

Abu El Enein, Ali Khalil Mustafa. (1988). Islamic Values And Education: A Study Of The Nature Of Values, Its References And The Role Of Islamic Education In The Formation And The Development Of It.

Abu Amsha, Ibrahim Basil. (2013). Social And Emotional Intelligence And Their Relation With Happiness For The University Students In Gaza, Master Thesis, Faculty Of Education-Department Of Psychology, Al Azhar University, Gaza.

Al Ahmad, Ayman Ahmad. (2009). The Self-Concept And Its Relation With The Sense Of Psychological Loneliness, Field Study Applied To A Sample Of Students Of Scientific Colleges, (Civil Engineering) And The Literary Colleges (Education) In Damascus University, Dr. Salwa Azzazi Site For Research And Studies.

Ahmad, Sameer Kamel. (2006). Emotional Education And Mental Health Of The Child, Paper Presented By The Annual Conference Of The College Of Kindergarten, Cairo University, Emotional Education For The Child (8-9/4/2006, 42-84).

Al Giolani, Fadia. (1997). Educational Sociology. Alexandria Book Center, Egypt, L1.

Al Hiyari, Mahmoud. (2009). Emotional Education For The Child: Islamic Vision. Jordanian Journal Of Educational Sciences, 5(4), 356-369.

Al Zoubi, Refaa. (2006). The Role Of The School In Emotional Education, Paper Presented At The Annual Conference Of The College Of Kindergarten, Cairo University, " Emotional Education For The Child 19/8,2006,463-478.

Al Sharif, Abdallah. (2017). Building Self Between Emotional And Emotional Intelligence, Http://Www.Charefab.Com, 7p-142.

Al Saqer, Taseer Mohamed. (2005). The Level Of Moral Growth And Perceived Self-Efficacy Among A Sample Of Yarmouk University Students In The Light Of Some Changes, A Magister Thesis That Is Not Published, Yarmouk University, Jordan.

Al Zaher, Khaled Shaker. (2004). Cognitive Self-Efficacy And Its Relation To Supportive Academic Practices, A Magister Thesis That Is Not Published, University Of Jordan, Amman.

Alwan, Taleb Sali. (2008). Self-Efficacy Of Students At Baghdad University. Journal Of Educational And Psychological Research, (33).

Ali, Amal Mahmoud. (2015). Development Of Moral Values In Light Of The Educational Thought Of Imam Ibn Al-Qayyim, An Analytical Study, University Of Medina International Court, No.(13), 163-175.

Aspy, D.N \& Roebuck, F. N. (1982). Affective Education: Sound investment. Educational: Leadership, 39(7), 488-493.

Graham, S, L. (2003). Instructional Design for Affective learning in Theogical Education, 14(1), 58-77.

Hens, B.; Rik, P.; \& Richard, p. (2008). Future oriented Emotion; conceptualization and Behavioral Effect. European Journal of Social Phycology, 38(4), 685-696.

Hansen, D. (1993). The Horizon of Moral: A Replay to David Bloom Curriculum inquiry, 23(2), 227-233.

Mortaja, Ahed Mahmoud Mohammed. (2004). The Extent To Which Secondary School Students Practice Moral Values From The Perspective Of Their Teachers In Gaza Governorate, Master Thesis, Faculty Of Education, Al Azhar University.

Meng; Z \& Lows, S. (2012). .Keep an Eya on Feelings: Interpersonal. Affective Forecasting anf Self - Regulation.

Sheldon, K .L. (1994). Including Affective and Social Eduction the Integrated Curriculum Paper presented at Annual Meeting of the Southeastern Regional Association of Teacher Educatiors, October ,11-15. 